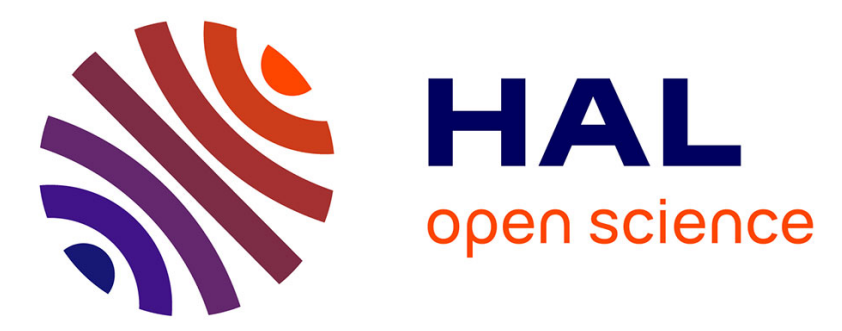

\title{
Unacylated ghrelin is not a functional antagonist but a full agonist of the type 1a growth hormone secretagogue receptor (GHS-R)
}

Carlotta Gauna, Bedette van de Zande, Anke van Kerkwijk, Axel P.N. Themmen, A.J. van Der Lely, Patric J.D. Delhanty

\section{To cite this version:}

Carlotta Gauna, Bedette van de Zande, Anke van Kerkwijk, Axel P.N. Themmen, A.J. van Der Lely, et al.. Unacylated ghrelin is not a functional antagonist but a full agonist of the type 1a growth hormone secretagogue receptor (GHS-R). Molecular and Cellular Endocrinology, 2007, 274 (1-2), pp.30. 10.1016/j.mce.2007.05.010 . hal-00531929

\section{HAL Id: hal-00531929 \\ https://hal.science/hal-00531929}

Submitted on 4 Nov 2010

HAL is a multi-disciplinary open access archive for the deposit and dissemination of scientific research documents, whether they are published or not. The documents may come from teaching and research institutions in France or abroad, or from public or private research centers.
L'archive ouverte pluridisciplinaire HAL, est destinée au dépôt et à la diffusion de documents scientifiques de niveau recherche, publiés ou non, émanant des établissements d'enseignement et de recherche français ou étrangers, des laboratoires publics ou privés. 


\section{Accepted Manuscript}

Title: Unacylated ghrelin is not a functional antagonist but a full agonist of the type 1a growth hormone secretagogue receptor (GHS-R)

Authors: Carlotta Gauna, Bedette van de Zande, Anke van Kerkwijk, Axel P.N. Themmen, A.J. van der Lely, Patric J.D.

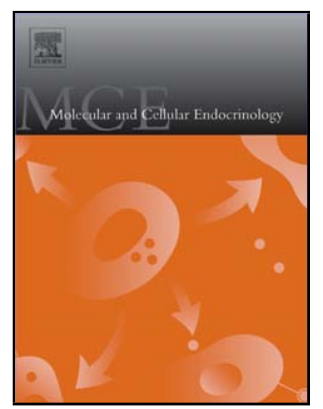

Delhanty

PII:

S0303-7207(07)00208-0

DOI: doi:10.1016/j.mce.2007.05.010

Reference: MCE 6660

To appear in: $\quad$ Molecular and Cellular Endocrinology

Received date: $\quad$ 24-1-2007

Revised date: $\quad$ 7-5-2007

Accepted date: $\quad$ 16-5-2007

Please cite this article as: Gauna, C., van de Zande, B., van Kerkwijk, A., Themmen, A.P.N., van der Lely, A.J., Delhanty, P.J.D., Unacylated ghrelin is not a functional antagonist but a full agonist of the type 1a growth hormone secretagogue receptor (GHSR), Molecular and Cellular Endocrinology (2007), doi:10.1016/j.mce.2007.05.010

This is a PDF file of an unedited manuscript that has been accepted for publication. As a service to our customers we are providing this early version of the manuscript. The manuscript will undergo copyediting, typesetting, and review of the resulting proof before it is published in its final form. Please note that during the production process errors may be discovered which could affect the content, and all legal disclaimers that apply to the journal pertain. 
Unacylated ghrelin is not a functional antagonist but a full agonist of the type 1a growth hormone secretagogue receptor (GHS-R)

Carlotta Gauna, Bedette van de Zande, Anke van Kerkwijk, Axel PN Themmen, AJ van der Lely, Patric JD Delhanty

Department of Internal Medicine, Erasmus MC, Rotterdam, The Netherlands

Acknowledgments: We thank Euroscreen s.a. (Gosselies, Belgium) for providing the Aequoscreen cells, and Dr M. Culler (Endocrinology Research Group, IPSEN Pharmaceuticals, MA) for providing the BIM28163. The study was supported by the Netherlands Organization for Scientific Research (NWO grant 912-03022).

Running title: GHS-R activation by UAG

Correspondence:

PJD Delhanty, Ph.D

Department of Internal Medicine,

Erasmus MC, Room Ee542,

P.O. Box 1738, 3000 DR Rotterdam,

The Netherlands

Email: p.delhanty@erasmusmc.nl

Tel.: $\quad+31104088197$

Fax: +31104635430 


\section{Abstract}

Recent findings demonstrate that the effects of ghrelin can be abrogated by coadministered unacylated ghrelin (UAG). Since the general consensus is that UAG does not interact with the type 1a growth hormone secretagogue receptor (GHS-R), a possible mechanism of action for this antagonistic effect is via another receptor. However, functional antagonism of the GHS-R by UAG has not been explored extensively. In this study we used human GHS-R and aequorin expressing $\mathrm{CHO}-\mathrm{K} 1$ cells to measure $\left[\mathrm{Ca}^{2+}\right]_{i}$ following treatment with UAG. UAG at up to $10^{-5} \mathrm{M}$ did not antagonize ghrelin induced $\left[\mathrm{Ca}^{2+}\right]_{\mathrm{i}}$. However, UAG was found to be a full agonist of the GHS-R with an $\mathrm{EC}_{50}$ of between 1.6 and $2 \mu \mathrm{M}$ using this in vitro system. Correspondingly, UAG displaced radio-labeled ghrelin from the GHS-R with an $\mathrm{IC}_{50}$ of $13 \mu \mathrm{M}$. In addition, GHS-R antagonists were found to block UAG induced $\left[\mathrm{Ca}^{2+}\right]_{i}$ with approximately similar potency to their effect on ghrelin activation of the GHS-R, suggesting a similar mode of action. These findings demonstrate in a defined system that UAG does not antagonize activation of the GHS-R by ghrelin. But our findings also emphasize the importance of assessing the concentration of UAG used in both in vitro and in vivo experimental systems that are aimed at examining GHS-R independent effects. Where local concentrations of UAG may reach the high nanomolar to micromolar range, assignment of GHS-R independent effects should be made with caution. 


\section{Introduction}

Ghrelin was discovered through its ability to activate the type 1a growth hormone secretagogue receptor (GHS-R) and stimulate growth hormone release in vivo (Smith et al., 2005; van der Lely et al., 2004). An evolutionarily conserved feature of ghrelin is the acylation of its third residue, usually with $n$-octanoic and, less commonly, with $n$-decanoic acid (Hosoda et al., 2003). Kojima et al (Kojima et al., 1999) were the first to describe the requirement that ghrelin be acylated on its third serine residue for activation of the GHS-R in the nanomolar range, with an $\mathrm{EC}_{50}$ for increased $\left[\mathrm{Ca}^{2+}\right]_{\mathrm{i}}$ of $2.5 \times 10^{-9} \mathrm{M}$. In the circulation, ghrelin also occurs as a unacylated isoform (UAG) at 10-50 times the concentration of acylated ghrelin (Kojima and Kangawa, 2005, and our unpublished observations).

Of great interest to us has been the finding that in humans co-administration of UAG can antagonize the metabolic effects of ghrelin in vivo. Ghrelin administration causes hyperglycemia, hypoinsulinemia, increased circulating free fatty acids and worsening insulin sensitivity, but these effects are reversed or prevented by co-administration with UAG (Broglio et al., 2004; Gauna et al., 2004). These effects seem to be specific to ghrelin's metabolic activity since UAG has no impact on GH, PRL or ACTH secretion (Broglio et al., 2004). This suggested a direct action on the endocrine pancreas, and perhaps on hepatic glucose production. In relation to these in vivo findings, we have shown that UAG 
not only suppresses glucose output, but also blocks ghrelin induced glucose release by primary hepatocytes (Gauna et al., 2005). In support of these findings, a recent report demonstrated the antagonistic effect in fish where ghrelin's orexigenic effects were blocked by administration of UAG. Furthermore, this effect appears to occur both centrally and peripherally (Matsuda et al., 2006). There are now many reports of direct biological activity of UAG in vitro that suggest a receptor mediated cellular response, perhaps via a specific receptor that is not GHS-R (Baldanzi et al., 2002; Cassoni et al., 2004; Chen et al., 2005; Gauna et al., 2006; Muccioli et al., 2004; Nanzer et al., 2004; Thompson et al., 2003; Toshinai et al., 2006). Despite these findings, the current consensus appears to be that UAG is inactive as an agonist of the GHS-R. However, the possibility remains that UAG is somehow able to block the ghrelin response by antagonizing the GHS-R. Therefore, we have explored in more detail, in a defined in vitro system, the ability of UAG to antagonize activation of the GHS-R by ghrelin, the potency of UAG at the GHS-R, and the effects of GHS-R antagonists. 


\section{Materials and Methods}

\section{Peptides}

Human UAG was obtained from NeoMPS (Strasbourg, France) and Thera Technologies (Montreal, Canada). Human ghrelin, [D-Lys ${ }^{3}$ ]GHRP-6, somatostatin28, obestatin and glucagon were obtained from NeoMPS. The ghrelin analog BIM28163, a potent antagonist of the GHS-R, was kindly provided by IPSEN Pharmaceuticals (Milford, MA). All peptides had been assessed for purity and integrity by high performance liquid chromatography and mass spectrometry.

\section{Aequoscreen assay for ghrelin and UAG activity}

Aequoscreen cells were kindly provided by Euroscreen s.a. (Gosselies, Belgium). These cells (CHO-A5) are stably transfected with a pIRES-puro (Clontech, Mountain View, CA) construct containing mitochondrially targeted apoaequorin which allows luminometric determination of [Ca $]_{i}$. An identical cell line was also provided that had also been stably transfected with a human GHSR1a expression construct with a Neo cassette (CHO-A5-GHSR). These cell lines were maintained in HAM F12 containing $10 \%$ fetal calf serum, $2.5 \mu \mathrm{g} / \mathrm{mL}$ amphotericin, $100 \mathrm{IU} / \mathrm{mL}$ penicillin, $100 \mu \mathrm{g} / \mathrm{mL}$ streptomycin, $5 \mu \mathrm{g} / \mathrm{mL}$ puromycin. The GHS-R expressing cells were maintained in the same medium but with the addition of $400 \mu \mathrm{g} / \mathrm{mL}$ G418. On the day of the assay the cells were resuspended in BSA assay buffer (DMEM/HAM's F12, with HEPES, without phenol red, $0.1 \%$ BSA, $2.5 \mu \mathrm{g} / \mathrm{mL}$ amphotericin, $100 \mathrm{IU} / \mathrm{mL}$ penicillin, $100 \mu \mathrm{g} / \mathrm{mL}$ streptomycin) at 
$5 \times 10^{6}$ cells $/ \mathrm{ml}$, and then coelenterazine $\mathrm{h}$ (Sigma, St Louis, MO) was added to a final concentration of $5 \mu \mathrm{M}$. Cells were incubated at room temperature for $4 \mathrm{~h}$ and kept in suspension by gentle rotation. Cells were then diluted with BSA assay buffer to $5 \times 10^{5}$ cells $/ \mathrm{ml}$, and $100 \mu \mathrm{L}$ was injected into wells of a black 96-well plate containing $100 \mu \mathrm{L}$ of various concentrations and combinations of ghrelin, UAG and other peptides. Luminescence was integrated for $15 \mathrm{~s}$ using a Victor2 1420 multilabel counter (Perkin-EImer, Wellesley, MA, USA), a short enough time that it is very unlikely that modification of the UAG could occur during the assay. After collection of data, the residual response of the cells was measured by permeabilizing their membranes with $100 \mu \mathrm{L}$ of $1 \%$ Triton $\mathrm{X}-100$. Data were calculated as the fractional response to agonist relative to the total response of the cells to agonist and Triton X-100 (fractional response $=x(x+y)^{-1}$, where $x=$ agonist response and $y=$ residual response). In experiments with antagonists we have normalized the data as percentage of maximal response in the absence of antagonist. UAG was able to saturate the response of the aequoscreen cells in the presence of an $\mathrm{EC}_{75}$ concentration of ghrelin (Fig1A). Therefore, we have set the maximal response of UAG at that of ghrelin in the correlation function used for regression analysis. Non-linear regression analysis was performed using Graphpad Prism version 3 (San Diego, CA).

\section{Radioligand binding studies}

Membranes were prepared from CHO-A5-GHSR cells using a protocol from Euroscreen. Briefly, cells at $80 \%$ confluence in monolayer culture in $75 \mathrm{~cm} 2$ 
flasks, were scraped into PBS, then pelleted at $1500 x g$ for $3 \mathrm{~min}$. The cell pellet was then resuspended in buffer $\mathrm{A}(15 \mathrm{mM}$ Tris- $\mathrm{HCl}(\mathrm{pH} 7.4), 2 \mathrm{mM} \mathrm{MgCl}, 0.3$ $\mathrm{mM}$ EDTA, $1 \mathrm{mM}$ EGTA) at $4^{\circ} \mathrm{C}$ and homogenized in a glass/teflon homogenizer. The crude membrane fraction was collected by two consecutive centrifugation steps at $40,000 \times \mathrm{g}$ for 25 min separated by a washing step in buffer $A$. Membrane pellets were resuspended in buffer B (75 mM Tris- $\mathrm{HCl}(\mathrm{pH} 7.5), 12.5$ $\mathrm{mM} \mathrm{MgCl} 2,0.3 \mathrm{mM}$ EDTA, $1 \mathrm{mM}$ EGTA, $250 \mathrm{mM}$ sucrose) and stored at $-80^{\circ} \mathrm{C}$ until use. Protein content was measured using the Biorad protein assay (Biorad, Hercules, CA).

Competitive binding dose curves for ghrelin and UAG were then run using $75 \mu \mathrm{g}$ of membrane protein and 50,000 cpm $(0.1 \mathrm{nM})$ of $\left[\mathrm{His}\left[{ }^{125} \mathrm{I}\right]\right]$-ghrelin (NEX388, Perkin-Elmer, Boston, MA) in binding buffer (25 mM HEPES pH7.4, 1 mM CaCl 2 , $5 \mathrm{mM} \mathrm{MgCl}_{2}$ ) in a total volume of $100 \mu \mathrm{L}$. Binding was carried out at $21^{\circ} \mathrm{C}$ for 60 min, then membranes were collected by centrifugation, washed with ice-cold binding buffer, and radioactivity was counted. Samples were run in duplicate. Non-linear regression analysis was performed using Graphpad Prism. 


\section{Results}

The main reason for examining UAG modulation of GHS-R activity was to elucidate a mechanism for our finding that this peptide could antagonize the effects of ghrelin on hepatocyte glucose production in vitro (Gauna et al., 2005). Therefore, the first experiment that we ran was designed to determine if UAG had any antagonistic activity in an in vitro system where we could examine its rapid effects directly. We have used Aequoscreen cells transfected with the human GHS-R (CHO-A5-GHSR) for this purpose, where the induction of $\left[\mathrm{Ca}^{2+}\right]_{\mathrm{i}}$ by exposure of the cells to ghrelin can be accurately and rapidly assessed by measuring aequorin luminescence. CHO-A5-GHSR cells are sensitive to ghrelin treatment, responding consistently and robustly with an $\mathrm{EC}_{50}$ of $\sim 2 \mathrm{nM}$ (Fig.1A). In initial experiments we treated the cells with $2.5 \mathrm{nM}$ or $5 \mathrm{nM}$ ghrelin (generating approximately 80 and $93 \%$ of their maximum luminescence response) together with increasing concentrations of UAG ranging from $10^{-10}$ to $10^{-5} \mathrm{M}$ (Fig. 1A). We found that over this dose range UAG does not antagonise ghrelin's action on the GHS-R. In fact, under conditions of sub-maximal stimulation with $2.5 \mathrm{nM}$ ghrelin, UAG in the low micromolar range was able to further stimulate the cells towards their maximal fractional response (in this case, $93 \%$ ).

The possibility remained that the CHO-A5 cells themselves contained a receptor that was responsive to UAG, and that the response we were measuring was not derived from activation of the GHS-R but from another receptor. Therefore, we tested the response to UAG and ghrelin in Aequoscreen cells that had not been 
transfected with the GHS-R. Dose response curves for UAG $\left(10^{-8} \mathrm{M}\right.$ to $\left.10^{-5} \mathrm{M}\right)$ and ghrelin $\left(10^{-10} \mathrm{M}\right.$ to $\left.10^{-7} \mathrm{M}\right)$ caused no luminescent response from these cells (Fig. 1A), whereas combined treatment with $0.5 \mu \mathrm{M}$ PMA and $100 \mathrm{nM}$ A23187 elicited a maximal fractional response of $0.98 \pm 0.003(n=4)$. These findings confirm that the response we have measured for UAG is not mediated by an alternative receptor system in $\mathrm{CHO}-\mathrm{A} 5$ cells. There was also the possibility that UAG was having a non-specific effect on receptor activation in the micromolar range. To test this we ran dose response curves for three other peptides of similar size but unrelated amino acid sequence (somatostatin28, obestatin and glucagon) at between $5 \times 10^{-11}$ and $10^{-5} \mathrm{M}$. None of these peptides generated a signal at any of the concentrations tested (Fig. 1B).

UAG may antagonise ghrelin's action at concentrations other than ghrelin's $\mathrm{EC}_{90}$. To test this possibility, we examined the response of the aequoscreen cells to UAG in the presence of ghrelin at concentrations that spanned its dose response curve. UAG had no antagonistic effect on any of these concentrations of ghrelin (Fig. 1C), and the results are fully consistent with UAG acting agonistically on the GHSR in the $10^{-7}$ to low $10^{-6} \mathrm{M}$ concentration range.

We also constructed dose response curves using two different sources of the peptide (NeoMPS and Thera Technologies). These experiments showed that UAG is a full agonist of the GHS-R with $E_{50}$ values of $1.6 \mu M\left(n=4, R^{2}=0.95\right)$ for NeoMPS peptide, and $2.1 \mu \mathrm{M}\left(\mathrm{n}=15, \mathrm{R}^{2}=0.94\right)$ for Thera Technologies peptide (Fig. 2A). Fractional response values of 0.84 and 0.89 were reached at $10 \mu \mathrm{M}$, 
which are close to the maximal response for ghrelin at $10 \mathrm{nM}$. The potency of UAG was further confirmed with membrane preparations of CHO-A5-GHSR cells. In radioligand binding experiments UAG displaced $\left[\mathrm{His}\left[{ }^{125} \mathrm{I}\right]-\right.$-ghrelin from the GHS-R with an $\mathrm{IC}_{50}$ of $13 \mu \mathrm{M}$ (Fig. 2B). Ghrelin demonstrated a typical displacement curve using the same membrane preparations (Fig. $2 \mathrm{~B} ; \mathrm{IC}_{50}, 7$ $\mathrm{nM})$.

As additional evidence that UAG was activating the GHS-R, we tested the ability of two GHS-R antagonists to block its effect. BIM28163 is an analog of full-length ghrelin (Halem et al., 2005), whereas [D-Lys ${ }^{3}$ GHRP-6 is an antagonistic analog of the hexapeptide growth hormone secretagogue GHRP-6 (Cheng et al., 1989). Both have been demonstrated to have antagonistic activity in vitro and in vivo (Cheng et al., 1989; Halem et al., 2005). Inhibitory dose response curves against UAG in GHS-R Aequoscreen cells demonstrated that both peptidyl antagonists were capable of blocking the UAG response (Fig. 3A; BIM28163 and [DLys ${ }^{3}$ ]GHRP-6; $238 \mathrm{nM}$ and $700 \mathrm{nM}$, respectively). The potencies of these antagonists was similar to those found against ghrelin using the same in vitro system (Fig. 3B; BIM28163 and [D-Lys ${ }^{3}$ ]GHRP-6; $240 \mathrm{nM}$ and $1.98 \mu \mathrm{M}$, respectively). These data suggest that UAG activates the GHS-R with a similar mechanism of action. 


\section{Discussion}

Overall, our observations in a cell line in which we can measure the effects of peptides exclusively on GHSR activation suggest that UAG can reinforce the activity of ghrelin, depending on effective concentrations. However in other in vitro models, and in vivo, the situation appears to be more complex. Previous studies show that UAG can displace radiolabelled ghrelin from membrane extracts of cell-lines that lack expression of GHS-R1a mRNA (eg. Cassoni et al., 2001; Muccioli et al., 2004), and that UAG can antagonise ghrelin induced glucose release in hepatocytes (Gauna et al., 2005) that probably do not express GHS-R1a. These studies present the argument that there is a separate UAG receptor that is involved in modulating the metabolic effects of ghrelin in vivo, for example on glucose homeostasis (Broglio et al., 2004; Gauna et al., 2004). In these instances, UAG could modulate the metabolic effects of ghrelin directly in the liver or pancreas directly on a receptor that is shared by ghrelin and UAG, or indirectly via a UAG-specific receptor. It is likely that a direct antagonistic effect of UAG on ghrelin activity at the GHSR is ruled out by our findings, strengthening the argument for an alternate receptor that is involved in the antagonistic effects of UAG.

However, we also demonstrate that UAG is capable of activating the GHS-R in the high nanomolar to low micromolar range in the Aequoscreen in vitro system. These are lower concentrations than previously determined, suggesting that UAG could activate GHS-R in other cellular systems, perhaps even in vivo. An 
important issue is whether local concentrations of UAG ever reach the levels needed for agonistic action on GHS-R. Hormone concentrations can reach levels in tissues that are not attained in the circulation, through local production. Examples of this include interleukin-6, and the peptide hormones angiotensin-I and angiotensin-II which have been demonstrated to attain tissue concentrations 100-fold higher than circulating levels (Sopasakis et al., 2004; van Kats et al., 2001). It has recently been demonstrated that UAG concentrations are in the nanomolar range in the pancreatic (splenic) vein resulting from high levels of local production in the pancreas (Dezaki et al., 2006). If, like the similarly sized angiotensins, pancreatic tissue levels of UAG were 100 -fold greater than in the circulation, then this would bring local concentrations into the range required to activate the GHS-R. Ghrelin appears to be synthesized in numerous tissues (Gnanapavan et al., 2002), in each of which local concentrations of both acylated and UAG may reach concentrations higher than those in the blood. Additionally, high local concentrations of UAG could also occur in certain experimental conditions, such as at the site of infusion of the peptide.

Bednarek et al (Bednarek et al., 2000) examined the requirement for a bulky hydrophobic group in the side chain of the $\mathrm{Ser}^{3}$ residue of ghrelin for its ability to activate GHS-R1a in a similar aequorin reporter system. This study found that human UAG activated the GHSR to $40 \%$ of maximal values at $10 \mu \mathrm{M}$. A similar structure-function study of rat ghrelin that measured $\left[\mathrm{Ca}^{2+}\right]_{i}$ mobilization using 
Fura2 has been described by Matsumoto et al (Matsumoto et al., 2001), with UAG activating the GHSR with an $\mathrm{EC}_{50}$ of $3.5 \mu \mathrm{M}$. Although these studies hinted at the activity of the des-octanoylated form of the peptide, they did not directly address the possibility of a functional antagonistic effect of UAG on this receptor. We find that human UAG activates the human GHSR with similar or greater potency to that of rat UAG, and that its mechanism of action is similar to that of ghrelin since GHSR antagonists block its action. Our data suggest UAG may act on the GHSR in a potentially physiological range of concentrations. At the very least, our findings illustrate that peptide concentration must be carefully considered in experiments where local concentrations of UAG may reach the low micromolar range in vivo, or in in vitro experiments.

In conclusion, we find in a defined in vitro system that UAG cannot functionally antagonize the action of ghrelin on the GHS-R. This suggests that the apparent antagonistic activity of UAG is mediated by an indirect mechanism, perhaps involving a specific UAG ghrelin receptor. UAG is a full agonist of the GHS-R, with activity in the high nanomolar range. The ability of UAG to interact with the GHS-R makes it necessary to interpret GHS-R independent activity of this peptide with caution in in vitro and in vivo experiments where the local peptide concentrations following treatment may reach the high nanomolar range. 


\section{References}

Baldanzi, G., Filigheddu, N., Cutrupi, S., Catapano, F., Bonissoni, S., Fubini, A., Malan, D., Baj, G., Granata, R., Broglio, F., Papotti, M., Surico, N., Bussolino, F., Isgaard, J., Deghenghi, R., Sinigaglia, F., Prat, M., Muccioli, G., Ghigo, E., Graziani, A., 2002. Ghrelin and des-acyl ghrelin inhibit cell death in cardiomyocytes and endothelial cells through ERK1/2 and PI 3kinase/AKT. J Cell Biol. 159, 1029-37.

Bednarek, M.A., Feighner, S.D., Pong, S.S., McKee, K.K., Hreniuk, D.L., Silva, M.V., Warren, V.A., Howard, A.D., Van Der Ploeg, L.H., Heck, J.V., 2000. Structure-function studies on the new growth hormone-releasing peptide, ghrelin: minimal sequence of ghrelin necessary for activation of growth hormone secretagogue receptor 1a. J Med Chem. 43, 4370-6.

Broglio, F., Gottero, C., Prodam, F., Gauna, C., Muccioli, G., Papotti, M., Abribat, T., Van Der Lely, A., Ghigo, E., 2004. Non-acylated ghrelin counteracts the metabolic but not the neuroendocrine response to acylated ghrelin in humans. J Clin Endocrinol Metab. 89, 3062-5.

Cassoni, P., Ghe, C., Marrocco, T., Tarabra, E., Allia, E., Catapano, F., Deghenghi, R., Ghigo, E., Papotti, M., Muccioli, G., 2004. Expression of ghrelin and biological activity of specific receptors for ghrelin and des-acyl 
ghrelin in human prostate neoplasms and related cell lines. Eur $\mathrm{J}$ Endocrinol. 150, 173-84.

Cassoni, P., Papotti, M., Ghe, C., Catapano, F., Sapino, A., Graziani, A., Deghenghi, R., Reissmann, T., Ghigo, E., Muccioli, G., 2001. Identification, characterization, and biological activity of specific receptors for natural (ghrelin) and synthetic growth hormone secretagogues and analogs in human breast carcinomas and cell lines. J Clin Endocrinol Metab. 86, 1738-45.

Chen, C.Y., Inui, A., Asakawa, A., Fujino, K., Kato, I., Chen, C.C., Ueno, N., Fujimiya, M., 2005. Des-acyl ghrelin acts by CRF type 2 receptors to disrupt fasted stomach motility in conscious rats. Gastroenterology. 129, 8-25.

Cheng, K., Chan, W., Barreto, A.J., Convey, E., Smith, R., 1989. The synergistic effects of His-D-Trp-Ala-Trp-D-Phe-Lys-NH2 on growth hormone (GH)releasing factor-stimulated $\mathrm{GH}$ release and intracellular adenosine $3^{\prime}, 5^{\prime}-$ monophosphate accumulation in rat primary pituitary cell culture. Endocrinology. 124, 2791-8.

Dezaki, K., Sone, H., Koizumi, M., Nakata, M., Kakei, M., Nagai, H., Hosoda, H., Kangawa, K., Yada, T., 2006. Blockade of pancreatic islet-derived ghrelin 
enhances insulin secretion to prevent high-fat diet-induced glucose intolerance. Diabetes. 55, 3486-93.

Gauna, C., Delhanty, P., van Aken, M., Janssen, J., Themmen, A., Hofland, L., Culler, M., Broglio, F., Ghigo, E., van der Lely, A., 2006. Unacylated ghrelin is active on the INS-1E rat insulinoma cell line independently of the growth hormone secretagogue receptor type 1a and the corticotropin releasing factor 2 receptor. Mol Cell Endocrinol. 251, 103-11.

Gauna, C., Delhanty, P.J., Hofland, L.J., Janssen, J.A., Broglio, F., Ross, R.J., Ghigo, E., van der Lely, A.J., 2005. Ghrelin stimulates, whereas desoctanoyl ghrelin inhibits, glucose output by primary hepatocytes. J Clin Endocrinol Metab. 90, 1055-60.

Gauna, C., Meyler, F.M., Janssen, J.A., Delhanty, P.J., Abribat, T., van Koetsveld, P., Hofland, L.J., Broglio, F., Ghigo, E., van der Lely, A.J., 2004. Administration of acylated ghrelin reduces insulin sensitivity, whereas the combination of acylated plus unacylated ghrelin strongly improves insulin sensitivity. J Clin Endocrinol Metab. 89, 5035-42.

Gnanapavan, S., Kola, B., Bustin, S.A., Morris, D.G., McGee, P., Fairclough, P., Bhattacharya, S., Carpenter, R., Grossman, A.B., Korbonits, M., 2002. 
The tissue distribution of the mRNA of ghrelin and subtypes of its receptor, GHS-R, in humans. J Clin Endocrinol Metab. 87, 2988.

Halem, H.A., Taylor, J.E., Dong, J.Z., Shen, Y., Datta, R., Abizaid, A., Diano, S., Horvath, T.L., Culler, M.D., 2005. A novel growth hormone secretagogue1a receptor antagonist that blocks ghrelin-induced growth hormone secretion but induces increased body weight gain. Neuroendocrinology. 81, 339-49.

Hosoda, H., Kojima, M., Mizushima, T., Shimizu, S., Kangawa, K., 2003. Structural divergence of human ghrelin. Identification of multiple ghrelinderived molecules produced by post-translational processing. J Biol Chem. 278, 64-70.

Kojima, M., Hosoda, H., Date, Y., Nakazato, M., Matsuo, H., Kangawa, K., 1999. Ghrelin is a growth-hormone-releasing acylated peptide from stomach. Nature. 402, 656-60.

Kojima, M., Kangawa, K., 2005. Ghrelin: structure and function. Physiol Rev. 85, 495-522. 
Matsuda, K., Miura, T., Kaiya, H., Maruyama, K., Shimakura, S., Uchiyama, M., Kangawa, K., Shioda, S., 2006. Regulation of food intake by acyl and desacyl ghrelins in the goldfish. Peptides. 27, 2321-2325.

Matsumoto, M., Hosoda, H., Kitajima, Y., Morozumi, N., Minamitake, Y., Tanaka, S., Matsuo, H., Kojima, M., Hayashi, Y., Kangawa, K., 2001. Structureactivity relationship of ghrelin: pharmacological study of ghrelin peptides. Biochem Biophys Res Commun. 287, 142-6.

Muccioli, G., Pons, N., Ghe, C., Catapano, F., Granata, R., Ghigo, E., 2004. Ghrelin and des-acyl ghrelin both inhibit isoproterenol-induced lipolysis in rat adipocytes via a non-type 1a growth hormone secretagogue receptor. Eur J Pharmacol. 498, 27-35.

Nanzer, A.M., Khalaf, S., Mozid, A.M., Fowkes, R.C., Patel, M.V., Burrin, J.M., Grossman, A.B., Korbonits, M., 2004. Ghrelin exerts a proliferative effect on a rat pituitary somatotroph cell line via the mitogen-activated protein kinase pathway. Eur J Endocrinol. 151, 233-40.

Smith, R.G., Jiang, H., Sun, Y., 2005. Developments in ghrelin biology and potential clinical relevance. Trends Endocrinol Metab. 16, 436-442. 
Sopasakis, V., Sandqvist, M., Gustafson, B., Hammarstedt, A., Schmelz, M., Yang, X., Jansson, P., Smith, U., 2004. High local concentrations and effects on differentiation implicate interleukin-6 as a paracrine regulator. Obes Res. 12, 454-60.

Thompson, N.M., Gill, D.A., Davies, R., Loveridge, N., Houston, P.A., Robinson, I.C., Wells, T., 2003. Ghrelin and des-octanoyl ghrelin promote adipogenesis directlyin vivo by a mechanism independent of GHS-R1a. Endocrinology. 145, 234-242.

Toshinai, K., Yamaguchi, H., Sun, Y., Smith, R.G., Yamanaka, A., Sakurai, T., Date, Y., Mondal, M.S., Shimbara, T., Kawagoe, T., Murakami, N., Miyazato, M., Kangawa, K., Nakazato, M., 2006. Des-acyl Ghrelin Induces Food Intake by a Mechanism Independent of the Growth Hormone Secretagogue Receptor. Endocrinology.

van der Lely, A.J., Tschop, M., Heiman, M.L., Ghigo, E., 2004. Biological, physiological, pathophysiological, and pharmacological aspects of ghrelin. Endocr Rev. 25, 426-57.

van Kats, J.P., Schalekamp, M.A.D.H., Verdouw, P.D., Duncker, D.J., Danser, A.H.J., 2001. Intrarenal angiotensin II: Interstitial and cellular levels and site of production. Kidney International. 60, 2311-2317. 


\section{Legends}

Fig.1 A. UAG does not antagonise ghrelin's action on the GHS-R. Open circles represent the $\left[\mathrm{Ca}^{2+}\right]_{i}$ response of CHO-A5-GHS-R cells to a dose curve of ghrelin. The cells' response to $2.5 \mathrm{nM}$ (triangles) and $5 \mathrm{nM}$ ghrelin (squares), in the absence (open symbols) and presence (closed symbols) of dose curves of UAG are superimposed on the ghrelin dose response curve. UAG further stimulates the effects of $2.5 \mathrm{nM}$ ghrelin, approaching the maximal response obtained with ghrelin alone (fractional response of 0.93). Neither ghrelin (open diamonds) nor UAG (closed diamonds) activate Aequorin cells that lack the GHS-R. B. Peptide ligands (somatostatin28, obestatin and glucagon) of similar molecular weight to UAG do not activate the GHS-R in aequoscreen cells in the $10^{-11}$ to $10^{-5} \mathrm{M}$ range. A ghrelin dose response was run concurrently as a positive control. C. UAG (open squares), activates the GHS-R with an EC50 in the low micromolar range, but does not antagonize activation of the GHS-R by ghrelin in a range of concentrations corresponding to $25-100 \%$ of maximal response (closed symbols represent UAG dose response curves run in increasing concentrations of ghrelin from 0.75 to $9 \mathrm{nM}$ ). The dose response for ghrelin is shown for comparison (open circles). Error bars represent \pm SEM.

Fig. 2. UAG is an agonist of the GHS-R. A. Dose response curves for UAG from two sources (NeoMPS, $n=4, E_{50}=1.6 \mu M$; and Thera Technologies, $n=15, E_{50}=$ 
$2.1 \mu \mathrm{M})$ on the CHO-A5-GHS-R cells. Measured endpoint is aequorin luminescence $B$. Displacement curves for [His[ $\left.{ }^{125} \mathrm{I}\right]$-ghrelin by ghrelin $\quad\left(\mathrm{IC}_{50}, 7\right.$ $\mathrm{nM})$ and UAG $\left(\mathrm{IC}_{50}, 13 \mu \mathrm{M}\right)$. Error bars represent \pm SEM.

Fig. 3. GHS-R antagonists antagonize both UAG and ghrelin with similar $I_{50}$ values. A. Inhibitory dose response curves against $5 \mu \mathrm{M}$ UAG in CHO-A5-GHS-R cells for BIM28163 (IC $50,240 \mathrm{nM})$ and [D-Lys $\left.{ }^{3}\right]$ GHRP-6 $\left(\mathrm{IC}_{50}, 700 \mathrm{nM}\right) . \mathrm{B}$. Inhibitory dose response curves against $5 \mathrm{nM}$ ghrelin in CHO-A5-GHS-R cells for BIM28163 (IC $50,240 \mathrm{nM})$ and [D-Lys $\left.{ }^{3}\right]$ GHRP-6 $\left(\mathrm{IC}_{50}, 1.98 \mu \mathrm{M}\right)$. Error bars represent \pm SEM. 

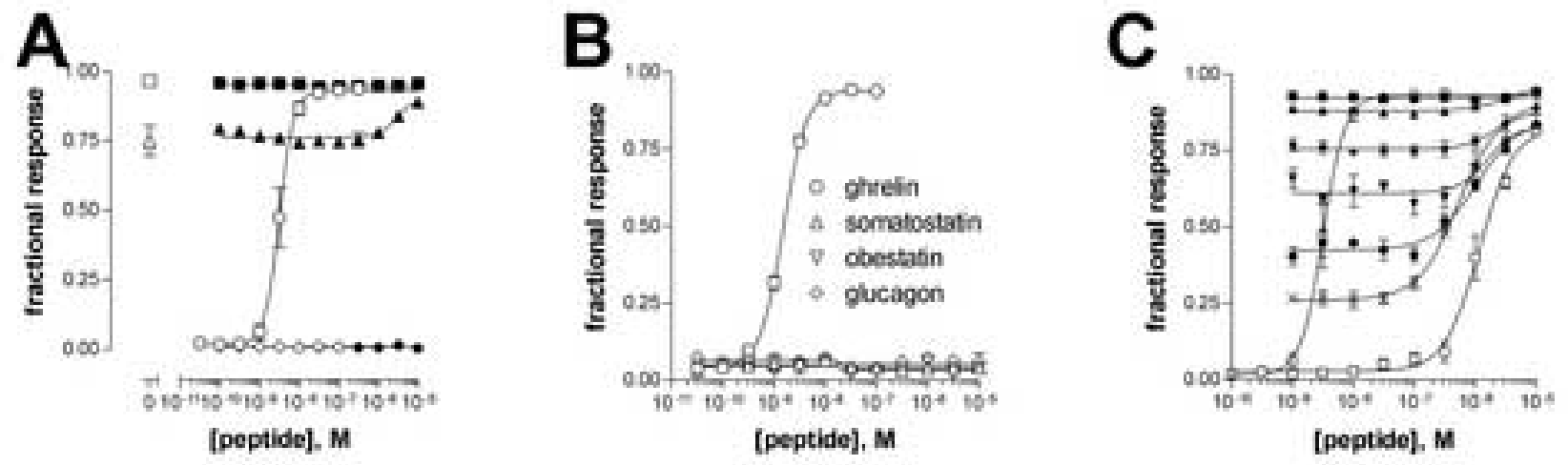

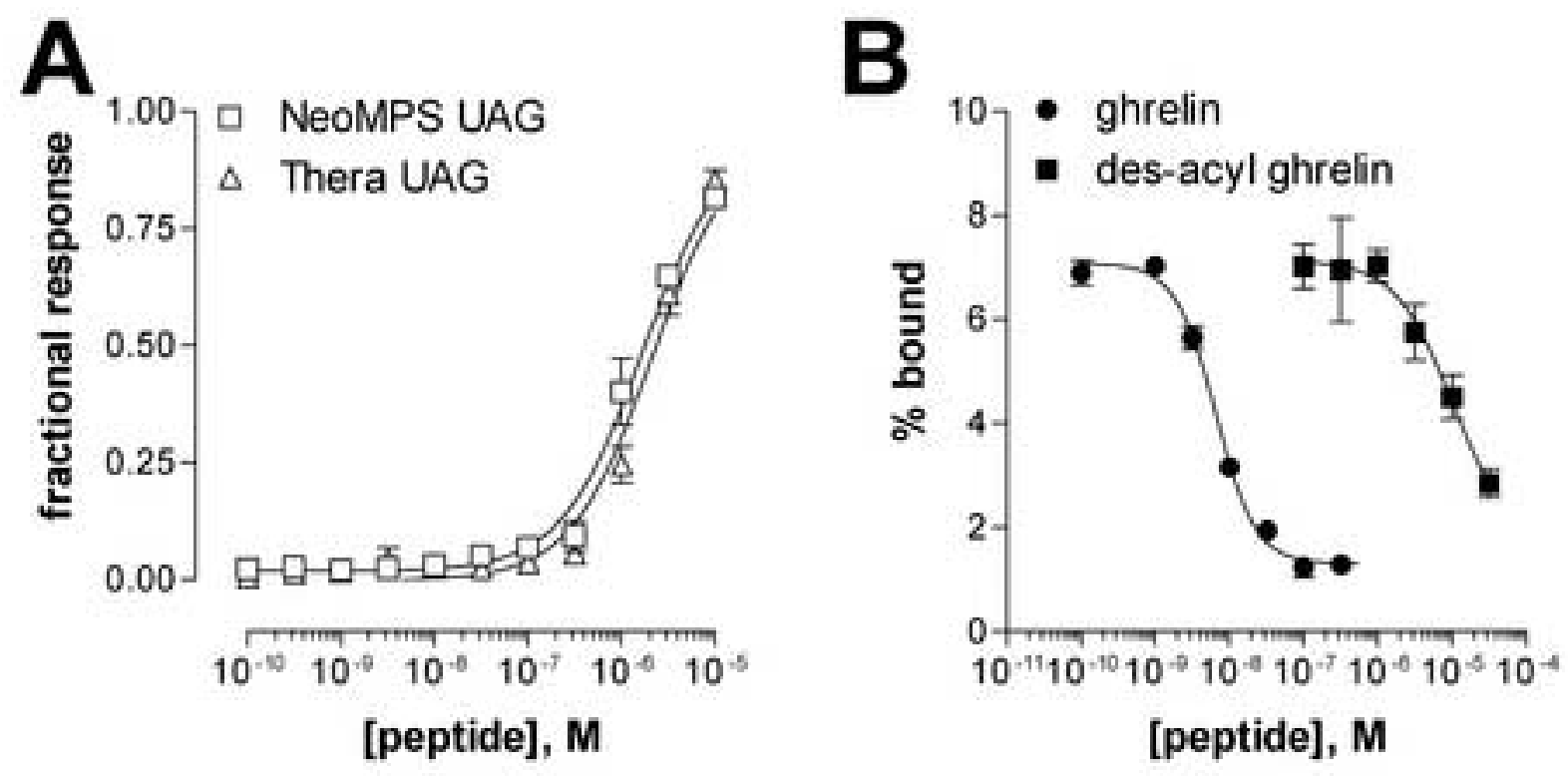
A
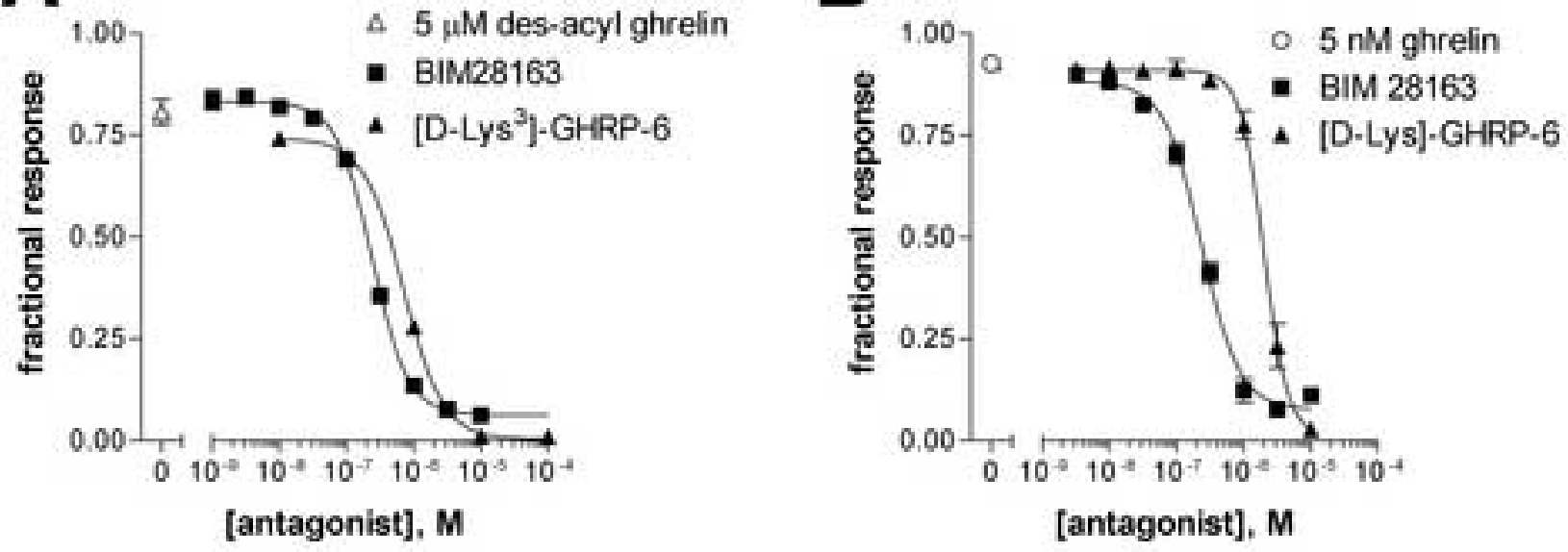